Artikel Penelitian

\title{
Pengaruh Pemberian Diet Tinggi Minyak Sawit terhadap Kadar Serum Glutamic Pyruvic Transaminase Darah Tikus Wistar Normal
}

\author{
Yenny Mayang Sari ${ }^{1}$, Susila Sastri ${ }^{2}$, Yustini Alioes ${ }^{2}$
}

\begin{abstract}
Abstrak
Diet tinggi minyak sawit adalah diet yang mengandung lemak 42-60\% kalori. Minyak sawit mengandung $50 \%$ saturated fatty acid (SFA), 40\% mono unsaturated fatty acid (MUFA), 10\% poly unsaturated fatty acid (PUFA) dan antioksidan seperti vitamin E dan karoten. SFA dapat meningkatkan penumpukan trigliserida pada USFA menurunkan deposit lipid dengan meningkatkan proses oksidasi. Apabila pengaruh SFA yang lebih dominan maka terjadi penumpukan lemak pada hati, sehingga terjadi peningkatan Serum Glutamate Piruvate Transferase (SGPT). Tujuan penelitian ini adalah menentukan pengaruh diet tinggi minyak sawit terhadap kadar SGPT darah tikus. Sampel terdiri dari 10 ekor tikus wistar jantan yang dibagi menjadi dua kelompok, yaitu kelompok tikus kontrol yang diberi diet standar dan kelompok tikus perlakuan yang diberi tambahan $42,5 \%$ minyak sawit kedalam diet standar. Kedua kelompok diberi makan secara adlibitum. Setelah perlakuan satu bulan, dilakukan pemeriksaan kadar SGPT. Hasil penelitian didapatkan perbedaan yang bermakna $(p<0,05)$ antara kadar SGPT kelompok tikus perlakuan yang diberi diet tinggi minyak sawit $(53,4 \pm 0,04 \mathrm{u} / \mathrm{l})$ dengan kelompok tikus kontrol yang diberi diet standar $(47,2 \pm 0,03 \mathrm{u} / \mathrm{l})$. Simpulan penelitian ini adalah diet tinggi minyak sawit dapat meningkatkan kadar SGPT darah.
\end{abstract}

Kata kunci: minyak sawit, tikus, SGPT

\section{Abstract}

High diet of palm oil containing $42-60 \%$ of calories comes from fat. Palm oil contains $50 \%$ SFA, $40 \%$ MUFA, $10 \%$ PUFA and antioxidant such as vitamin E and carotene. SFA can increase the accumulation of triglycerides in adipose, while USFA can lower lipid deposits by increasing oxidation process. If a more dominant influence SFA then in the accumulation of fat in the liver, resulting in increased SGPT. The objective of this study was to determine the effect of a high palm oil diet on SGPT concentration in rat's normal blood. Sample consisted of 10 male wistar rats, were divided into two research namely a control group which was administrated standard diet and treatment group rats which were administrated addition of $42,5 \%$ palm oil to standart diet. The second group was fed adlibitum. After one month treatment, SGPT concentration was observed. The results showed that there was a significant difference $(p<0.05)$ between SGPT concentration in treatment group rats were fed high diet of palm oil $(53,4 \pm 0,04 \mathrm{u} / \mathrm{l})$ and control group rats were fed a standart diet $(47,2 \pm 0.03 u / l)$. It can be concluded that high diet of palm oil could increase concentration of SGPT in the rat's normal blood.

Keywords: palm oil, rat, SGPT

Affiliasi penulis: 1. Prodi Profesi Dokter FK Unand (Fakultas Kedokteran Universitas Andalas Padang), 2. Bagian Biokimia FK Unand.

Korespondensi: YennyMayang Sari, Email:

yennymayangsari@gmail.com, Telp: 085355199842

\section{PENDAHULUAN}

Minyak sawit mengandung asam lemak jenuh dan tak jenuh yang seimbang. Minyak sawit mengandung asam lemak jenuh $44 \%$ (SFA) dan $50 \%$ 
asam lemak tidak jenuh (USFA). ${ }^{1}$ SFA (Saturated Fatty Acid) dalam sel hepatosit akan menurunkan proses oksidasi dengan cara menurunkan AMPK-1C dan CPT-1. ${ }^{2}$ Saturated Fatty Acid (SFA) juga akan meningkatkan asam lemak dalam darah. Pada awal peningkatan asam lemak dapat kembali menjadi kadar normal melalui lipogenesis pada sel adiposity dan oksidasi asam lemak pada hepatosit, tetapi bila jumlah konsumsi asam lemak berlebihan dapat menyebabkan pembentukan trigliserida yang berlebihan. ${ }^{3}$ Minyak sawit juga mengandung USFA (Unsaturated Fatty Acid), USFA tidak menyebabkan peningkatan trigliserida karena mudah mengalami oksidasi. ${ }^{4}$

Fatty liver adalah kondisi yang ditandai dengan adanya akumulasi lemak ( $5 \%$ dari berat badan) didalam sel hepatosit hati, yang disebabkan oleh ketidak seimbangan antara produksi dan sekresi trigliserida oleh hati. ${ }^{5}$ Penyebab paling banyak fatty liver adalah konsumsi alkohol yang berlebihan (46$50 \%$ ) yang disebut dengan alcoholic fatty liver disease (AFLD) dan obesitas (76-90\%) yang disebut dengan non alcoholic fatty liver disease (NAFLD). ${ }^{6}$ Patogenesis non alcoholic fatty liver adalah peningkatan asam lemak bebas di hati melebihi kapasitas oksidatifnya. $^{7}$

Peningkatan asam lemak dalam darah akan dibawa ke hepar untuk mengalami proses oksdiasi tetapi karena SFA menyebabkan penurunan oksidasi asam lemak akan disimpan dalam bentuk trigliserida. ${ }^{8}$ Penumpukan trigliserida akan menyebabkan peningkatan TNF- $\alpha$. TNF- $\alpha$ akan meningkatkan NADPH oksidase yang akan menghasilkan radikal superoksida yang sangat reaktif karena mempunyai dua elektron yang tidak berpasangan, terutama sangat reaktif terhadap lipid sehingga menyebabkan peroksidasi lipid. Peroksidasi lipid akan menyebabkan perubahan permeabelitas pada sel hati sehingga, akan menyebabkan enzim yang dihasilkan oleh sel hati terutama Serum Glutamate Piruvate Transferase (SGPT) akan meningkat dalam darah. ${ }^{9}$

\section{METODE}

Desain penelitian ini adalah eksperimental post test only control group design. Populasi dalam penelitian ini adalah tikus galur wistar yang memiliki berat badan antara 180-250 gram dan umur 2 bulan.
Diet standar tikus mengandung $75 \%$ karbohidrat, $7,5 \%$ lemak dan $15 \%$ protein, sedangkan minyak sawit yang digunakan adalah minyak goreng yang dijual bebas di pasaran. Binatang percobaan sebelum diperlakukan dibiarkan dalam kandang selama satu minggu untuk adaptasi.

Kemudian:

- Kelompok kontrol, yaitu kelompok terdiri dari 5 ekor tikus yang diberi diet standar ad libitium selama 4 minggu, pemeriksaan kadar SGPT darah dilakukan pada hari terakhir penelitian.

- Kelompok diet tinggi minyak sawit, yaitu kelompok terdiri dari 5 ekor tikus yang diberi diet standart ditambah $50 \%$ minyak sawit ad libitum selama 4 minggu. Pemeriksaan kadar SGPT darah dilakukan pada hari terakhir penelitian.

Data profil SGPT darah tikus disajikan dalam bentuk tabel. Uji statistik dilakukan secara komputerisasi. Perbedaan rerata antar kelompok ditentukan dengan uji Anova setelah dilakukan uji normalitas.

HASIL

Tabel.1 Hasil pemeriksaan SGPT

\begin{tabular}{llc}
\hline No & \multicolumn{1}{c}{ KelompokTikus } & $\begin{array}{c}\text { Kadar SGPT } \\
\text { (Rerata } \pm \text { SD) }\end{array}$ \\
\hline 1. & Kelompok kontrol $(\mathrm{n}=5)$ & $47,2 \pm 3.27$ \\
2. & Kelompok diet tinggi & $53,4 \pm 4.72$ \\
& minyak sawit $(\mathrm{n}=5)$ & \\
&
\end{tabular}

Hasil uji normalitas kormogorov-Smirnov dan Shapiro-Wilk didapatkan distribusi data normal, kemudian dianalisis dengan t-test. Hasil uji menunjukkan rerata kadar SGPT kelompok tikus perlakuan lebih tinggi signifikan dibandingkan kelompok kontrol.

\section{PEMBAHASAN}

Kadar SGPT lebih tinggi pada kelompok diet tinggi minyak sawit juga didapatkan oleh Imafidon et al tahun 2012 yang menunjukan peningkatan kadar SGPT serum pada tikus yang diberi diet tinggi minyak sawit selama 6 minggu. ${ }^{10}$ Alaam et al pada tahun 2012 juga menyatakan diet tinggi minyak sawit akan dapat 
meningkatkan kadar SGPT di dalam darah di karenakan diet tinggi minyak sawit dapat menyebabkan gangguan dan disfungsi pada sel hati. ${ }^{11}$

Peningkatan kadar SGPT pada kelompok diet tinggi minyak sawit dikarenakan terjadi peningkatan trigliserida dan juga reaksi stress oksidatif yang mengakibatkan kerusakan pada hepar sehingga SGPT meningkat di dalam darah. ${ }^{12}$

\section{SIMPULAN}

Kelompok tikus dengan diet tinggi minyak sawit memperlihatkan peningkatan kadar SGPT darah dibandingkan kelompok kontrol.

\section{DAFTAR PUSTAKA}

1. Sundram K, Sambanthamurti R, Ai Tan Y. Palm fruit chemistry and nutrition. Asia Pasific J Clinical Nutr. 2003;12(3):355-62.

2. Dowman J K, Tomlinson J W, Newsome $\mathrm{P} \mathrm{N}$. Pathogenesis of non alcoholic fatty liver disease. QJ Med. 2010;103:71-83.

3. Sastri S, Kadri H. Pengaruh diet tinggi minyak sawit terhadap sel hepatosit tikus. Jurnal Kesehatan Andalas. 2012;1(3):125-8.

4. Leamy A K, Robert A G, Young J D. Molecular mechanism and the role of saturated fatty acids in the progression of non alcoholic fatty liver disease. Progress in lipid research. 2013;165-74.
5. David A, Parke C, Kapil B. Non alqoholic fatty liver disease: a clinical review. Digestive disease and science. 2005;11-18.

6. Bellentani S, BedogniG, Miglioli L, Tiribelli C. The epidemiology of fatty Liver. European Journal of Gastroenterology and Hepatology. 2004;16:108793.

7. Ekstedt. Nonalqoholic fatty liver disease a clinical and histopatological study. Division of Gastroenterology and Hepatology. 2008;108.

8. Green A, Rumberger J M, Stuart C A, Ruhoff M S. Stimulation of lipolysis tumor necrosis factor- $\alpha$ in 3T3-L1 Adipocytes Is Glucose Dependent Diabetes. Diabetic. 2004;53.

9. Bellentani S, BedogniG, Miglioli L, Tiribelli C. The epidemiology of fatty Liver. European Journal of Gastroenterology and Hepatology. 2004;16:108793.

10. Imafidon K E, Okunrobo L O. Study on biochemical indices of liver function test of albino rats supplemented with three sources of vegetables oil. Nigerian Journal Of Basic and Applied Science. 2012;105-10.

11. Alaam M H, Yasin M N, Hafez S A, Mohammed H I. Biological and histological evaluations of palm oil and its fractions. World Journal of dairy and food sciences. 2012;120-30.

12. Panjaitan $\mathrm{P}$, et al. Pengaruh pemberian karbon tetraklorida terhadap fungsi hati dan ginjal tikus. Makalah Kesehatan. 2012;11(1):11-6. 